\title{
Going Public: Key Factors to Consider by IPO Candidates on Emerging Markets of Poland and the Czech Republic
}

\author{
Tomas Meluzin, Marek Zinecker, Natalja Lace
}

Brno University of Technology

Kolejni 2906/4, CZ-61200, Brno, Czech Republic

E-mail.meluzint@fbm.vutbr.cz,zinecker@fbm.vutbr.cz

Riga Technical university

Kalnciema street 6, LV-1048 Riga, Latvia

E-mail.Natalja.Lace@rtu.lv

cross $^{\text {ref }}$ http://dx.doi.org/10.5755/j01.ee.27.4.14755

Increasing globalization contributes to the growing role primary capital markets play for raising external equity capital. This phenomenon is becoming more significant in both developed and emerging countries and influences the effectiveness of national economy. We survey 45 chief financial officers (CFOs) from not public and not financial companies operating in the Czech Republic and Poland to document the internal determinants of going public. We use statistical analyses and comparison with recent academic literature and empirical evidence to interpret the survey-gained data. First, the most important IPO motivations are enhanced publicity and reputation of the company and establishment of the firm's market value. These benefits are expressed by CFOs across all firms and in both countries. A considerably larger number of CFOs is motivated by raising external equity capital. Surveyed companies tend to conduct an IPO in the expansion stage of their life cycle. Next, the significance of other going public determinants differs between Czech and Polish respondents and across companies varying in size and age. Third, our findings indicate that theories on IPO formulated for welldeveloped capital markets can explain going public determinants in smaller emerging markets. We suggest that our evidence can be a source of knowledge for enterprises while formulating new financial strategies. Furthermore, we also expect that survey results will be beneficial for investment bankers, stock exchanges and macroeconomic policy makers while discussing and designing incentives to attract more enterprises onto the primary capital markets under the specific conditions of the Czech Republic and Poland.

Keywords: IPO, Going Public, IPO Determinants, Motivations, Poland, the Czech Republic.

\section{Introduction}

Although the continental financial system is traditionally focused on banking, there is increasing interest in the stock markets and initial public offering (IPO) implementation (e.g. Pagano et al., 1998; Black \& Gilson, 1998; Chemmanur \& Fulghieri; 1999; Ritter \& Welch, 2002; Lizinska \& Czapiewski, 2016). This trend is also supported by the policy makers as follows from the Entrepreneurship 2020 Action Plan (2013) where European Commission sets out a number of actions to be taken to support entrepreneurship by developing an EU regime for exchanges trading in shares and bonds issued by small and medium enterprises (SMEs).

Recent empirical research and theoretical discourse identified many determinants that may have significant effects on the financing choice of enterprises through initial public offerings on well-developed capital markets of the USA and Western Europe. However, there have been relatively few empirical studies that have examined this issue in the Central and Eastern European (CEE) markets, which are supposed to have "different risk and return characteristics compared with developed EU's markets" (Lizinska \& Czapiewski, 2016). Therefore, in this study we intend to fill this gap in the academic IPO literature by analysing original data from a survey of chief financial officers (CFOs) covering a sample of non-quoted and nonfinancial common stock companies operating in the Czech Republic and Poland to answer the question on what determinants influence the decision of going public in these countries in recent years. Specifically, we investigate the internal IPO drivers, which are financial and non-financial, within subsamples defined on the basis of five criteria (conditional variables). The first criterion is country of origin; therefore we have Czech and Polish subsamples. Based on the second (age), third (size), fourth (ownership) and fifth (industry) criterion, there are the following subsamples: young and old, small and large, domestic and foreign and high-tech and conventional.

The novelty of this study consists in the research approach which is based on gathering of primary data as such data is currently not available. To our knowledge, previous literature has not documented determinants expressed by CFOs toward going public in the unlisted group of companies in any of the CEE countries and, thus, the theory and corporate practice grapple with insufficient empirical results. Furthermore, we address the question whether the recent IPO theory can be applied to the economic environment of the Eastern European emerging capital markets.

The survey results contribute to the better understanding of decision making on IPO in the sector of 
private enterprises. Revealing motivations to go public is a starting-point while formulating new financial strategies of e.g. banking or venture capital backed companies. We also expect that our findings will be beneficial for investment bankers, stock exchanges and macroeconomic policy makers while discussing and designing incentives to attract more enterprises onto the primary capital markets under the specific conditions of the Czech Republic and Poland.

The methods employed in this article include systematic and logical literature analysis, collection of original data (structured interviews and questionnaires were applied), statistical analysis of survey-gained data, comparison and expert interpretations.

The rest of this paper proceeds as follows. First, we review the literature on external and internal IPO determinants. Section 3 provides an overview of the data collection, hypotheses and methodological approach. Section 4 presents detailed findings and the last section discusses and summarises the main conclusions.

\section{IPO Determinants - A Theoretical Framework}

Recent academic literature indicates number of factors taking influence on going public activity at macro- level including business cycle, interest rates, sentiments on financial markets and regulatory constraints (e.g. Rydqvist \& Hogholm, 1995; Ljungqvist, 1995; Benninga et al., 2005; Gunther \& Rummer, 2006; Ritter, 2011). The comprehensive academic research on IPO drivers on micro- level suggests that the overall economic situation and in-house (internal) determinants indicate the positive or negative attitudes towards going public strategy.

Ritter \& Welch (2002) point out the situation of a company which needs to obtain external funds to undertake net present value projects. Raising funds through an IPO should be an alternative to borrowing, particularly in companies with high investments, high proportion of debt in the capital structure, and high potential for growth. Chemmanur \& Fulghiery (1999) addressed the question at what stage in its life should a firm go public rather than undertake its projects using private equity financing. The authors developed a model on going public decision in an asymmetric information framework as a trade-off between the option to raise equity financing in public markets compared to the private sale of equity to a small group of large investors. The model implies that companies tend to go public when sufficient information about them is accumulated in the public. In general, the older and better established a firm is, the higher the probability of the IPO. High-tech companies represent the only exception to this pattern, because they have a greater need for public funding.

The trade-off theory views the going public strategy as a tool how to achieve an optimal capital structure and to lower the cost of capital (Scott, 1976; Modigliani \& Miller, 1958, 1963). Rajan (1992) argues that going public may reduce the cost of credit, possibly because firms achieve a better bargaining position with banks. Pagano et al. (1998) proved these theories by investigating a comprehensive data set of Italian companies. They conclude that U.S. companies usually undergo a considerable growth process after listing while the decision of Italian independent companies can be interpreted as "an attempt to rebalance their balance sheet after large investments and growth", i.e. to reduce company indebtedness and cost of capital and achieve a stronger bargaining position with banks.

Zingales (1995) and Black \& Gilson (1998) argue that going public is the way how the majority shareholder's desire to reduce his stake in the company. An IPO is a vehicle to enhance stock liquidity and firm value. This enables owners to sell their shares in the company on public capital markets, which provides them more flexibility in their financial decision making. In addition to equity portfolio diversification, an IPO allows venture capitalists to cash out and resolves the problem of generational succession in a family-run enterprise.

Some authors have examined the theory that companies go public primarily to pursue M\&A strategy. An IPO allows the firm to value its capital and public shares serve as a "currency" in future M\&A. Brau \& Fawcett (2006) investigated 336 nonfinancial U.S. companies that had successfully completed an IPO or attempted and subsequently withdrew an IPO. More than a half of the interviewed CFOs strongly supported the notion that an IPO allows firms to create public shares that are used for growth through M\&A. The validity of this theory was also confirmed by Celikyurt et al. (2010), Hovakimian \& Hutton (2010), Brau et al. (2012) and Lyandres et al. (2011) who documented a high frequency of acquisitions by companies shortly after going public.

Going public is also associated with non-financial effects. Maksimovic \& Pichler (2001) suggest that the public trading of stocks can enhance the publicity and reputation of the firm. The prestige can be very advantageous in raising capital for growth, recruiting key employees as well as marketing products and services. Brau $\&$ Fawcett (2006) documented this IPO motivation on the US market.

Empirical research on going public determinants covers predominantly the US capital market. Surveys conducted in Europe are rather rare. Bancel \& Mittoo (2009) surveyed CFOs from 12 Western European countries regarding the determinants of going public and exchange listing decisions. Their evidence suggest that "the most CFOs identify enhanced visibility and financing for growth as the most important benefits of an IPO, but other motivations for IPOs differ significantly across firms, countries, and legal systems". The authors conclude that the IPO decision making cannot be explained by one single theory because companies seek multiple motivations, which are influenced by factors such as firm's ownership structure, size, age and home country's institutional and regulatory environment.

A very limited research has been conducted on IPO in the $\mathrm{CEE}$ region and there is a lack of survey based empirical results. Peterle \& Berk (2016) studied IPO drivers between 2000 and 2009 in seven CEE markets. The IPO drivers are divided into two main categories: macro and micro factors. Based on secondary data, descriptive statistics and hypotheses testing the authors conclude that the most relevant drivers for IPO volume are investor sentiments and business cycles. In a previous paper Peterle (2013) concludes that capital market factors such as "market size, liquidity and market capitalisation to GDP do not have a decisive impact on IPO activities in the 
CEE region". On the other hand, "the attractiveness of the capital market as measured by annual stock index returns and by annual market and liquidity growth" may have been an incentive for decision-makers about IPOs in the observed period.

Another study for the CEE region was conducted by Jargot (2006). The author investigated the determinants that influence the decision of Polish companies to go public and the consequences that an IPO may have on the company's performance based on accounting data from the period 1997-2004. The study has been carried out by comparing companies that went public with those that remained private. The research approach used an ex ante (probit model) and ex post firms' characteristics (fixedeffects model). The result of analyses revealed that Polish firms that went public were rather large, risky, highly leveraged, unable to generate sufficient funds internally, and they conducted IPO after periods of investments. The main determinant of companies was not to finance future investments, but the time of primary issue "in order to take advantage of window opportunity created by overoptimistic investors".

Bistrova et al. (2011) investigated the impact of going public decisions on the equity performance and profitability of 36 "blue-chip" companies listed on the Baltic stock exchanges between 2007 and 2010. The results of the study discovered "a positive relationship between stock performance and sufficiency of equity capital". Moreover, there was found an inversed relationship between the level of debt and capital profitability confirming the pecking order theory. The findings suggest using selfgenerated funds to going public strategy. In another investigation of the Baltic IPOs Bistrova \& Lace (2010) demonstrate that the profitability of the companies declines in the first two years after the funds attraction and that the solvency position strengthens right after the event but in the second year it reaches the level of pre-IPO financial stability. The authors offer two explanations of this phenomenon. The first one consist in a weak earnings quality before going public and the next one in a low motivation of the management to keep company attractive for investors, "which can be characteristic trait of developing equity market where investor relations culture is just emerging".

Our previous studies dealing with the issue of internal IPO determinants were based on investigations in Polish enterprises that have previously executed a primary issue or were IPO candidates, i.e. entities that have not executed an IPO, but considered doing so in the past or were candidates for doing it in the future (Meluzin \& Zinecker, 2014a Meluzin \& Zinecker, 2014 ${ }^{\mathrm{b}}$ ). However, no previous literature covers internal IPO determinants in the unlisted group of companies on two CEE capital markets, which differ substantially in the development of security markets. As the Czech stock exchange experienced a relative failure in the 1990s the development of Polish primary capital market is considered as a success story (Kominek, 2003). The Warsaw Stock Exchange also dominated the decade after 2000 and was often ranked second or third by IPO value in the EU (Peterle, 2013; Berk \& Peterle, 2016). As the average number of IPOs per year is lower than one at the Prague Stock Exchange and bank backed loans are prevailing funding source of enterprises, we believe that the different development of both capital markets offers a unique opportunity for a comparative study of IPO determinants. Accordingly, we formulate the following hypothesis:

Hypothesis 1: Statistically significant differences exist in the frequency of individual IPO determinants within the Czech and Polish subsamples.

Brau \& Fawcett (2006) attempted to explore the issue whether there are differences in CFOs' motivations in enterprises which differ in size, age, industry and IPO status. He concludes that "enhancing firm reputation and attracting analysts' attention motivate smaller, younger, high-tech, and VC-backed firms more than their counterparts". In contrast, CFOs in firms with large insiders are more concerned about "establishing a market price". Bancel \& Mittoo (2009) documented that most CFOs viewed enhanced visibility and financing for growth as the most important benefits of an IPO. However, other motivations for IPOs differ significantly across firms, countries, and legal systems. Accordingly, we assume that "enhancing the firm's reputation" as an IPO determinant is dominant in young, small, high-tech and knowledgeintensive enterprises while CFOs in well-established firms operating in predominantly conventional industries are driven by other factors. Accordingly, the next set of hypotheses is as follows:

Hypothesis 2: In young enterprises, the significance of "enhancing the firm's reputation" is higher than in their mature peers.

Hypothesis 3: In small enterprises, the significance of "enhancing the firm's reputation" is higher than in large companies.

Hypothesis 4: In high-tech and knowledge-intensive enterprises, the significance of "enhancing the firm's reputation" is higher than in companies operating in conventional industries.

Egger et al. (2010) compared domestically and foreign-owned plants with respect to their debt-to-assets ratio using data from 32,067 European firms. They argue that the debt-to-asset ratio of comparable foreign- and domestically owned firms differs, because foreign companies can better exploit tax-induced advantages of debt financing than national firms. Thus, we suggest that enterprises with foreign ownership are less motivated by individual IPO factors due to, e.g. corporate taxation or alternative opportunities how to raise external capital outside the organized capital market (e.g. they are equipped with capital provided by foreign parent companies). These considerations lead to our last hypothesis:

Hypothesis 5: In companies with domestic ownership structure, the significance of individual IPO determinants is higher than in foreign-owned firms.

\section{Data and Methodology}

The nature of this study is based on the theory, previous empirical research of corporate finance-oriented academic literature (Brau \& Fawcett, 2006; Bancel \& Mittoo, 2009; Snieska \& Venckuviene, 2011; Snieska et al., 2016) and analyses of original survey-gained primary data. Therefore, 
research methods cover the comparative analysis of scientific literature documents and reports, collecting primary data and its processing while using statistical methods.

The technique of primary data collection was a survey of a target group of respondents. The main advantage of the survey approach is that we can directly ask questions on issues (variables) that may not be publicly available. On the other hand, surveys measure beliefs and not necessary actions of managers. This is considered to be their drawback (Bancel \& Mittoo, 2009).

An opinion-attitude questionnaire in Polish and Czech language was employed. Our sample covers 45 IPO candidates operating in the Czech Republic and Poland. All surveyed entities have not executed an IPO, but considered doing so in the past or were candidates for doing it in the future. It is difficult to estimate how large is the group of companies that have not entered the capital market through an IPO but considered doing so in the past or are poised for a future filing. Nonetheless, a database of 60 companies (potential IPO candidates) was compiled from the information provided by brokers who had the experience of implementing IPOs on the Polish capital market. Mailing list of the Czech subsample was constructed as follows. We asked the Czech Statistical Office to provide us with a database of non-quoted nonfinancial common stock companies with headquarters in the Czech Republic, which are according to European Commission Regulation No. 800/2008 considered as large, i.e. companies with assets equal to or higher than 43 Million Euro, sales equal or higher than 50 Million Euro and number of employees equal or higher than 250 . We obtained 167 valid addresses and supposed these enterprises are large enough to go public.

The questionnaire with a cover letter was sent by email to all 60 companies in the Polish group in 2012. To boost the return rate, a second request for participation in the survey was e-mailed to all CFOs one month later. In the end, 18 completed questionnaires were received, which represents a $30 \%$ response rate. In early 2014, the questionnaire accompanied by a personalized and signed cover letter was sent to all companies on the Czech survey list. To increase the return rate, the questionnaire was put into an electronic form and, in June, sent by an e-mail to the respondents who had not replied the first time around, with a request for completion. Overall, 27 CFOs submitted usable answers (i.e. the response rate is $16.17 \%$ ). It should be pointed out that the return rates fall within the range mentioned in other survey-based financial studies (Brau \& Fawcett, 2006; Bancel \& Mittoo, 2009). The time-gap between the Polish and Czech survey is due to the fact that we explored the Polish capital market firstly. This data set was originally intended to investigate what determinants motivate companies that went public or considered this strategy (IPO candidates) in Poland after 2000. Because we also wanted to find out what factors motivate Czech IPO candidates, we conducted a follow-up survey on the Czech capital market in 2014.

The questionnaire-collected data was treated by statistical methods reflecting its nature and quantity. In order to test our hypotheses we performed univariate analyses on each survey question while quantitative data was evaluated by the Chi-Square Test to detect whether significant differences between the defined subsamples exist. Statistical data was processed at the significance level of $\alpha=5 \%$. The Principal Component Analysis (PCA) was applied in order to convert our original set of overall observations of possibly correlated IPO determinants into a set of principal components. The entire statistical evaluation was performed by Statistica.CZ software, version 12 .

\section{Overall Sample Description and Qualifications of Respondents}

Table 1 reports descriptive statistics on our entire sample and Czech and Polish subsamples. The first lines report the frequency of young and old companies. Those with the founding year before 1996 (the median) are considered old. The "size", is based on number of employees, total assets and sales. Enterprises are classified as large if number of employees exceeds 250 or total assets are greater than 43 Million Euro or the amount of annual sales is larger than 50 Million Euro (European Commission Regulation No. 800/2008). The share of large companies in our sample oscillates around $80 \%$, no matter how the size has been defined. High-tech is an indicator variable that equals one when the firm is operating in the high-tech industry and two otherwise. Companies operating in conventional industries comprise $76 \%$ in our sample. The last conditioning variable, "ownership", equals one when the shares are predominantly in the hands of domestic, i.e. either Czech or Polish, shareholders and two otherwise. Table 1 shows that $64 \%$ of firms are held by domestic shareholders and $36 \%$ are controlled by a foreign parent company.

Table 2 proves the qualifications of our respondents to go public. The respondents were asked to indicate, on a five-point Likert scale with two extreme anchors, 1 (unimportant) and 5 (of a high significance), their answer to the following question: "How important were/are the considerations for conducting an IPO in your company within the last five years?" This question was asked to prove the qualifications of our respondents. We assume that decision makers in companies with the intention to go public will respond in a more qualified and sophisticated way. The results of descriptive analysis are expressed as an arithmetic mean \pm standard deviation followed by the relative frequency of answers 4 and 5 (Table 2). The survey results for the overall set of respondents indicate that the considerations for bringing the company onto a public capital market were rather less significant $(2.13 \pm 1.47 ; 22.22$ $\%)$; however, the Polish companies are more likely to conduct an IPO $(3.39 \pm 1.54 ; 55.55 \%)$ than their Czech counterparts $(1.30 \pm 0.54 ; 0.00 \%)$. This is not surprising in view of the role the Polish capital market plays in corporate financing in Poland. Surprisingly, based on conditioning variables we can conclude that mainly respondents from small companies believe that a going public strategy should be followed. 
Overall Sample Description

\begin{tabular}{|c|c|c|c|c|c|c|}
\hline \multirow[t]{2}{*}{ VARIABLE } & \multicolumn{2}{|r|}{ In All } & \multicolumn{2}{|r|}{ Czech } & \multicolumn{2}{|r|}{ Polish } \\
\hline & Frequency & In \% of All & Frequency & In \% of Total & Frequency & In \% of Total \\
\hline Young (<18 Years) & 21 & 47 & 13 & 48 & 8 & 44 \\
\hline Old $(>18$ Years $)$ & 24 & 53 & 14 & 52 & 10 & 56 \\
\hline No. of Employees - Small $(<250)$ & 10 & 22 & 0 & 0 & 10 & 56 \\
\hline No. of Employees - Large $(>250)$ & 35 & 78 & 27 & 100 & 8 & 44 \\
\hline Total Assets - Small $(<43$ Million $€)$ & 11 & 24 & 2 & 7 & 9 & 50 \\
\hline Total Assets - Large ( $>43$ Million $€)$ & 34 & 76 & 25 & 93 & 9 & 50 \\
\hline Sales - Small $(<50$ Million $€$ per Year $)$ & 7 & 16 & 0 & 0 & 7 & 39 \\
\hline Sales - Large $(>50$ Million $€$ per Year) & 38 & 84 & 27 & 100 & 11 & 61 \\
\hline High-Tech & 11 & 24 & 6 & 22 & 5 & 28 \\
\hline Conventional & 34 & 76 & 21 & 78 & 13 & 72 \\
\hline Domestic & 29 & 64 & 15 & 56 & 14 & 78 \\
\hline Foreign & 16 & 36 & 12 & 44 & 4 & 22 \\
\hline In Total Czech/Polish/All & 45 & 100 & 27 & 100 & 18 & 100 \\
\hline
\end{tabular}

Note: The sample consisted of 45 completed surveys involving not-tried IPOs from the period of 2012-2014. The Czech subsample consisted of 27 completed surveys involving sufficiently large companies to conduct an IPO in the year 2014 . The Polish sample consisted of 18 completed surveys involving sufficiently large companies to conduct an IPO in the year 2012.

Table 2

Survey Results to the Question "How Important Were/Are the Considerations for Conducting an IPO?"

\begin{tabular}{|c|c|c|c|c|}
\hline & \multicolumn{4}{|c|}{ Survey Responses } \\
\hline & Mean & Median & $\begin{array}{l}\text { Standard } \\
\text { Deviation }\end{array}$ & $\begin{array}{c}\% \\
4-5\end{array}$ \\
\hline Overall & 2.13 & 1.00 & 1.47 & 22.22 \\
\hline Czech Subsample & 1.30 & 1.00 & 0.54 & 0.00 \\
\hline Polish Subsample & 3.39 & 4.00 & 1.54 & $\mathbf{5 5 . 5 5}$ \\
\hline Young (<18 Years) & 2.00 & 2.00 & 1.30 & 28.57 \\
\hline Old $(>18$ Years $)$ & 2.25 & 1.00 & 1.62 & 29.17 \\
\hline No. of Employees - Small $(<250)$ & 3.80 & 4.00 & 1.40 & 70.00 \\
\hline No. of Employees - Large $(>250)$ & 1.66 & 1.00 & 1.11 & 8.57 \\
\hline Total Assets - Small $(<43$ Million $€)$ & 3.27 & 4.00 & 1.74 & 54.55 \\
\hline Total Assets - Large ( $>43$ Million $€)$ & 1.76 & 1.00 & 1.18 & 11.77 \\
\hline Sales - Small $(>50$ Million $€$ per Year $)$ & 3.57 & 4.00 & 1.62 & $\mathbf{5 7 . 1 4}$ \\
\hline Sales - Large $(<50$ Million $€$ per Year $)$ & 1.87 & 1.00 & 1.30 & 15.79 \\
\hline High-Tech & 2.46 & 2.00 & 1.69 & 36.36 \\
\hline Conventional & 2.03 & 1.00 & 1.40 & 17.65 \\
\hline Domestic & 2.45 & 2.00 & 1.57 & 31.03 \\
\hline Foreign & 1.56 & 1.00 & 1.09 & 25.00 \\
\hline
\end{tabular}

Note: Means are based on a five-point scale ranging from 1 (not important) to 5 (very important).

\section{Survey Results}

\section{Overall Sample - Descriptive Statistics}

The respondents were asked to indicate, on a five-point Likert scale (1-unimportant, 5-very important), "how important are the following determinants for conducting an IPO?" Table 3 reports the survey results for an all-inclusive set of respondents and compares Czech and Polish companies. The results of the descriptive data analysis are expressed as an arithmetic mean \pm standard deviation followed by the relative frequency of answers 4 and 5 .

We find that over $55 \%$ of the CFOs agree that the main going public motivation is to raise capital before undergoing a considerable growth process after listing within the overall sample of respondents $(3.29 \pm 1.46 ; 55.55 \%)$. Thus, the cash raised in the IPO is primarily used for financing investment opportunities and the evidence does not support the theories that the fresh capital is perceived as an appropriate way of indebtedness reduction. Only $20 \%$ of firms report that a leverage reducing might be a very important IPO motivation $(2.42 \pm 1.12 ; 20.00 \%)$. The support of interviewed CFOs to the determinant that an IPO may enhance the firm's bargaining power with banks and consequently increase the willingness of financial creditors to provide loans with lower interest rates and longer payback periods is also rather moderate $(2.96 \pm 1.09 ; 40.00$ $\%)$. A small share of respondents also supports the cost of capital theory implying that firms go public to achieve an optimal capital structure and to lower their cost of capital $(2.51 \pm 1.24 ; 25.58 \%)$.

A going public strategy is strongly perceived as a tool how to remove the uncertainty about the precise value of firm's capital. Almost $56 \%$ respondents expect that that the trading of shares on a public capital market will prove useful in company valuation $(3.49 \pm 1.01 ; 55.81 \%)$. This motivation seems, however, not to be consistent with the theory that the valuation of stocks by the public capital market and their trading could be advantageous in using newly issued shares in future M\&A $(3.01 \pm 1.09 ; 27.27 \%)$ or in cashing out in the case of venture capitalists $(2.07 \pm$ $1.23 ; 22.73 \%$ ).

Non-financial motivations for going public attracted relative to financial motivations comparable attention in the point of "enhancing firm reputation and publicity". A majority of CFOs strongly supports the opinion that listed 
companies are viewed as the best in their industry and that an IPO is an attribute of a successful management of the company $(3.32 \pm 1.05 ; 50.00 \%)$. The second investigated non-financial motivation - "enhancing attractiveness as an employer" - received a rather low support $(2.84 \pm 1.12$; $31.82 \%)$.

\section{IPO Determinants in Czech and Polish Companies - A Comparison}

Further treatment of data sought to determine whether statistically significant differences exist in the frequency of respondents' answers in Czech and Polish companies. Table 3 compares the mean (median) rating of CFOs' responses from both countries on individual IPO motivations. Moreover, we calculate the chi-square test and its values in the last column indicate that statistically significant differences exist at the $5 \%$ level in the frequency of several IPO determinants. These differences are evident from the standard deviation values when Polish subsample exhibits a lower standard deviation and therefore lower data variability.

Firstly, raising external capital through public issues is a very important reason for $90 \%$ of Polish respondents; this result differs significantly from the Czech subsample, where $56 \%$ of CFOs are less concerned about the possibility of raising capital within a going public strategy $\left(\chi^{2}=16.00 ; \mathrm{df}\right.$ $=2 ; \mathrm{p}<0.05)$. The next result shows that a statistically significant difference exists in the frequency of responses to "the reducing the cost of capital" $\left(\chi^{2}=15.15\right.$; df $=2 ; \mathrm{p}<$ 0.05). While $50 \%$ of Polish CFOs believe an IPO strategy may lower the cost of capital, their Czech counterparts $(63 \%)$ viewed this motivation as rather unimportant and ranked it as seventh among the determinants. The last result indicates that the monitored groups of respondents have a different attitude towards the "reducing company indebtedness" $\left(\chi^{2}=9.98 ; \mathrm{df}=2 ; \mathrm{p}<0.05\right)$. Almost $73 \%$ of the Polish respondents acknowledge that lowering leverage might be a very or moderately significant reason to join a stock exchange. This result differs strongly from the perceptions of Czech CFOs. Attempting an IPO because of decreasing indebtedness is a determinant with a very low support for $74 \%$ of respondents.

Taken together, our findings support the Hypothesis 1 in relation to the three IPO determinants. Nevertheless, in relation to the remaining factors, the Hypothesis 1 has been rejected. The evidence suggests that market value establishment and publicity and image enhancement received a strong support in both monitored group of respondents. The views of Czech and Polish CFOs are also similar to the "stronger bargaining position with banks". 40 $\%$ of respondents in each group agree that this motivation plays a rather moderate role. Finally, we find a little support to "equity portfolio diversification", "exit of venture capitalists", "solving the problem of succession" and "attractiveness as an employer" as IPO motivations in both subsamples of managers.

We applied the Principal Component Analysis (PCA) in order to convert our original set of overall observations of possibly correlated IPO determinants into a set of principal components. We aim to amend the findings of the chisquare test and find out whether it is possible to define principal IPO drivers within the observed groups of enterprises. We use correlations between three principal components and the original variables for the following interpretations. Correlations value above \pm 0.6 is deemed important.

We reduced the amount of 11 original variables to 3 main factors (principal components) within the Polish subsample. From the Eigenvalue plot it is possible to say that with 3 principal components around $57 \%$ of the variation in the data can be explained. Figure 1 shows that in Poland, the first principal component is strongly correlated with four of the original variables $(a, b, c$ and $d$ ). Thus, the first principal component is positive correlated with raising external capital (0.83), reducing company indebtedness (0.64), stronger bargaining position $(0.65)$ and reducing the cost of capital (0.82). We suggest that this component can be viewed as a measure of the financing strategy. Companies go public to raise new capital and strengthen the bargaining position with banks to lower the cost of debt, which will decrease their financing costs. The second principal component is positively correlated with only one of the original variables, market value establishment (0.72), and negative correlated with equity portfolio diversification (-0.71). This component can be viewed as a measure of how important the IPO is for valuing the company in terms of existing shareholders. The third principal component increases with decreasing value of the variable $k(-0.70)$. This suggests that the CFOs do not tend to conduct the IPO strategy to use newly issued share as a currency for acquisitions and mergers.

Within the Czech subsample the Eigenvalue plot of around $65 \%$ makes it possible to explain the variation in the data with 3 principal components as well. The first component is negatively correlated with reducing the cost of capital (-0.66) and market value establishment (-0.71). This component can be explained as a measure of how important the going public strategy is to lower the cost of capital. The more the IPO strategy will be followed, the less the CFOs are concerned about the cost of capital. Other determinants play a more significant role within IPO considerations. In particular, the correlations between the second principal component and the original set of variables play a crucial role for our interpretations. Figure 2 reveals that the variables $a, b$ and $e$ are strongly correlated with this component in a negative direction. The second principal component increases with decreasing propensity of CFOs to raise capital, reduce company indebtedness and diversify equity portfolio. Thus, we could state that this principal component is primary a measure of the financing strategy. The third principal component is strongly correlated in a negative direction with exit of venture capitalists $(-0.82)$. This suggests that this component can be viewed as a measure of the exit strategy. CFOs in venture capital backed firms will not follow the IPO to cash out. 
Survey Results to the Question "How important were/are the Following Determinants of Conducting an IPO"? (Overall and Czech and Polish Subsample)

\begin{tabular}{|c|c|c|c|c|c|c|c|c|}
\hline & & \multicolumn{2}{|l|}{ Overall } & \multicolumn{5}{|c|}{ Country of Origin } \\
\hline & & \multirow[b]{2}{*}{ Mean (Median) } & \multirow[b]{2}{*}{$\begin{array}{c}\% \\
4-5\end{array}$} & \multicolumn{2}{|c|}{ Czech Subsample } & \multicolumn{2}{|c|}{ Polish Subsample } & \multirow[b]{2}{*}{ Chi-Square Test (df; p) } \\
\hline & & & & Mean (Median) & $\begin{array}{c}\% \\
4-5 \\
\end{array}$ & Mean (Median) & $\begin{array}{c}\% \\
4-5 \\
\end{array}$ & \\
\hline & \multicolumn{8}{|l|}{ Financial determinants } \\
\hline $\mathrm{a}$ & Raising external capital & $3.29(4.00)$ & 55.55 & $2.52(2.00)$ & 33.34 & $4.44(5.00)$ & 88.89 & $16.00(2 ;<0.05)$ \\
\hline b & Reducing company indebtedness & $2.42(2.00)$ & 20.00 & $2.04(2.00)$ & 14.82 & $3.00(2.00)$ & 27.78 & $9.98(2 ;<0.05)$ \\
\hline $\mathrm{c}$ & Stronger bargaining position & $2.96(3.00)$ & 40.00 & $2.78(3.00)$ & 40.74 & $3.22(3.00)$ & 38.89 & $3.27(2 ; 0.194)$ \\
\hline d & Reducing the cost of capital & $2.51(3.00)$ & 25.58 & $1.92(1.50)$ & 7.41 & $3.41(4.00)$ & 50.00 & $15.15(2 ;<0.05)$ \\
\hline $\mathrm{f}$ & Exit of venture capitalists & $2.07(2.00)$ & 22.73 & $1.85(1.00)$ & 18.52 & $2.39(2.00)$ & 27.78 & $0.70(2 ; 0.704)$ \\
\hline g & Solving the problem of succession & $1.93(1.00)$ & 11.37 & $1.96(1.50)$ & 11.11 & $1.89(1.00)$ & 11.11 & $0.054(2 ; 0.974)$ \\
\hline $\mathrm{j}$ & Market value establishment & $3.49(4.00)$ & 55.81 & $3.38(3.50)$ & 48.15 & $3.64(4.00)$ & 61.11 & $1.152(2 ; 0.562)$ \\
\hline \multirow[t]{2}{*}{$\mathrm{k}$} & Acquisitions and mergers & $3.02(3.00)$ & 27.27 & $3.15(2.00)$ & 33.33 & $2.83(3.00)$ & 16.67 & $1.741(2 ; 0.419)$ \\
\hline & Non-financial determinants & & & & & & & \\
\hline $\mathrm{h}$ & Publicity, image enhancement & $3.32(3.50)$ & 50.00 & $3.12(3.00)$ & 40.74 & $3.61(4.00)$ & 61.11 & $2.084(2 ; 0.353)$ \\
\hline $\mathrm{i}$ & Attractiveness as an employer & $2.84(3.00)$ & 31.82 & $2.65(3.00)$ & 25.92 & $3.11(3.00)$ & 38.89 & $1.414(2 ; 0.493)$ \\
\hline
\end{tabular}

Note: Means are based on a five-point scale ranging from 1 (not important) to 5 (very important). The sample consisted of 45 completed surveys involving 27 Czech and 18 Polish companies. The $p$-values indicate simultaneous differences using the chi-square test.
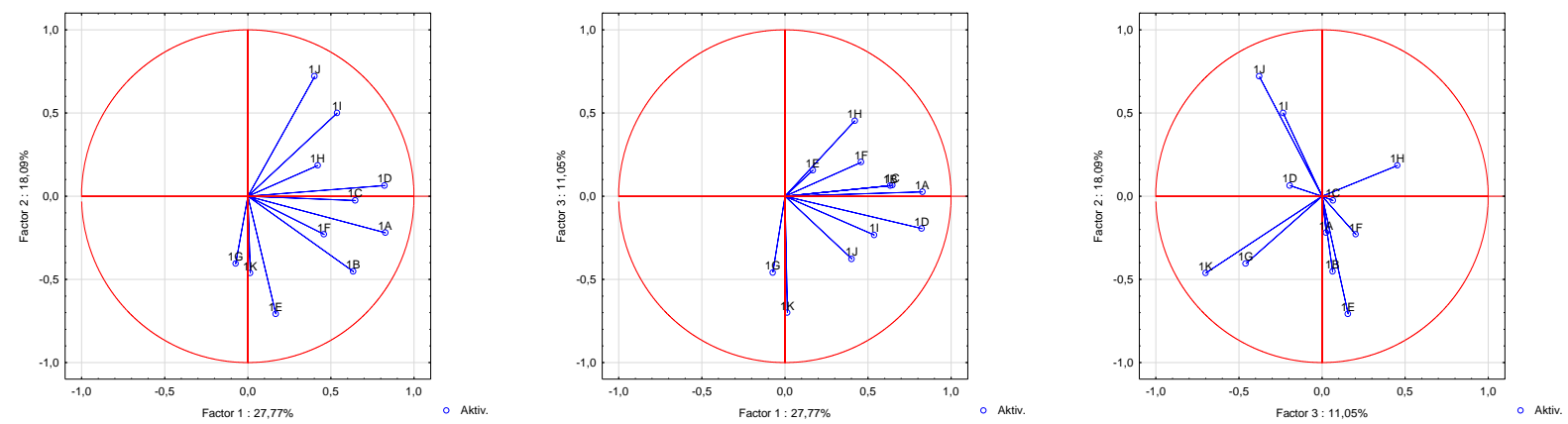

Figure 1. Projection of the Variables on the Factor-Plane $(1 \times 2)$ - Polish Subsample
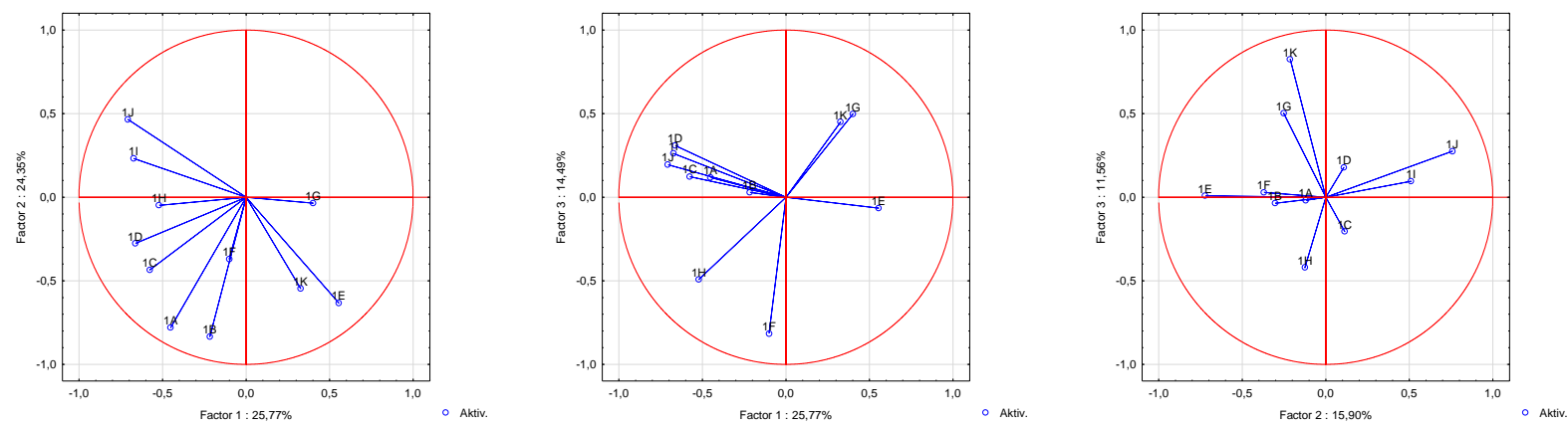

Figure 2. Projection of the Variables on the Factor-Plane $(1 \times 2)$ - Czech Subsample

\section{Conditioning Variables}

Analysing conditioning variables based on the chisquare test reveals some more insights on the issue of IPO determinants. Firstly, motivations for an IPO differ significantly across companies when taking into account the age as the conditioning variable. Table 4 shows that predominantly old firms are driven by "reducing indebtedness". One third of CFOs believes that IPO could be a tool to reduce leverage; their young peers, however, do not share this opinion $\left(\chi^{2}=6.13\right.$; $\left.\mathrm{df}=2 ; \mathrm{p}=0.047\right)$. More than $58 \%$ of CFOs working in older firms desire to strengthen the bargaining power towards external capital providers. The young companies place a significantly lower value on this factor $\left(\chi^{2}=10.05\right.$; $\mathrm{df}=2$; $\left.\mathrm{p}<0.05\right)$. Nevertheless, both groups assign a high ranking to other aspects of going public. CFOs from young and old companies view raising external capital and as the major benefit of an IPO and $62 \%$ of young and $46 \%$ of old companies tend to strongly agree that the public trading of shares is a valuable tool for business valuation. Our analysis also indicates that CFOs from both groups perceive the going public strategy as "rather important" from the "publicity and image enhancement" perspective as well as from the "attractiveness as an employer" perspective. Therefore, our findings could not support the Hypothesis 2 that young companies are mainly driven by enhancing the firm's reputation, which differs them from mature firms. Secondly, the goal of reducing the cost of capital as an important IPO determinant ranks higher in firms, which are classified as small in terms of all three examined perspectives (number of employees, value of 
assets and value of sales). Survey findings in Table 7 indicate that an absolute majority of CFOs in small companies are significantly more concerned about the cost of capital than large companies (small/employees: $\chi 2=$ 9.79; $\mathrm{df}=2 ; \mathrm{p}=0.007 ;$ small/assets: $\chi 2=9.48 ; \mathrm{df}=2 ; \mathrm{p}<$ 0.05 ; small/sales: $\chi 2=7.39$; $\mathrm{df}=2 ; \mathrm{p}=0.025)$. Raising external capital also received the highest score in small firms and a significant difference could be indicated between small and large enterprises when number of employees is taken into account $(\chi 2=6.58$; $\mathrm{df}=2 ; \mathrm{p}=$ 0.037). Moreover, $82 \%$ of CFOs in small firms view "enhancing the reputation" as a very strong determinant. Chi-square test indicate a statistically significant difference in the frequency of responses to this issue for firms considered as small by value of assets $(\chi 2=6.61$; $\mathrm{df}=2 ; \mathrm{p}$ $=0.036$ ). This result supports our Hypothesis 3; hence smaller companies are determined more by enhancing firm reputation than large companies. Thirdly, Table 5 shows survey results for companies, which are classified as operating in high-tech or conventional industry. Based on chi-square test we can conclude that the Hypothesis 4 has not been proved to be correct. Publicity and image enhancement as an IPO motivation is dominant not only in high-tech and knowledge-intensive enterprises. This motivation also ranks as the third most importnant in companies operating in convenctional industries. Furthermore, we found that raising external capital (hightech: $3.82 \pm 1.12 ; 81.82 \%$; conventional: $3.12 \pm 1.05$; $47.06 \%$;) and makret value establishment (high-tech: 3.50 \pm 1.19 ; $60.00 \%$; conventional: $3.48 \pm 1.03 ; 54.55 \%$;) are perceived as very important IPO determinants in both subsamples. Finally, we find no disparities between CFOs motivations operating in foreign and domestic companies. Thus, we reject our Hypothesis 5 that ownership structure has an impact on CFOs' considerations. Both groups of respondents are driven mainly by the following determinants: raising external capital (domestic: $3.38 \pm$ 1.06 ; $58.62 \%$; foreign: $3.13 \pm 1.02 ; 50.00 \%$ ), market value establishment (domestic: $3.46 \pm 1.18 ; 53.57 \%$; foreign: $3.53 \pm 1.12 ; 60.00 \%)$ and publicity and image enhancement (domestic: $3.28 \pm 1.01 ; 44.83 \%$; foreign: $3.40 \pm 1.16 ; 60.00 \%)$. Other results support the notion that the significance of individual IPO determinants is comparable independently of the ownership structure.

Table 4

Survey Results to the Question "How Important were/are the Following Determinants of Conducting an IPO"? (Young and Old Companies)

\begin{tabular}{|c|c|c|c|c|c|c|}
\hline & & \multicolumn{5}{|c|}{ Age } \\
\hline & & \multicolumn{2}{|c|}{ Young } & \multicolumn{2}{|c|}{ Old } & \multirow{2}{*}{$\begin{array}{c}\text { Chi-Square Test (df; } \\
\text { p) }\end{array}$} \\
\hline & & Mean (Median) & $\begin{array}{c}\% \\
4-5 \\
\end{array}$ & Mean (Median) & $\begin{array}{c}\% \\
4-5 \\
\end{array}$ & \\
\hline & \multicolumn{6}{|l|}{ Financial determinants } \\
\hline A & Raising external capital & $3.23(3.00)$ & 47.62 & $3.33(4.00)$ & 62.50 & $2.68(2 ; 0.262)$ \\
\hline B & Reducing company indebtedness & $2.14(2.00)$ & 4.76 & $2.67(2.50)$ & 33.33 & $6.13(2 ; 0.047)$ \\
\hline $\mathrm{C}$ & Stronger bargaining position & $2.76(3.00)$ & 19.05 & $3.13(4.00)$ & 58.33 & $10.05(2 ;<0.05)$ \\
\hline $\mathrm{D}$ & Reducing the cost of capital & $2.43(3.00)$ & 19.05 & $2.59(3.00)$ & 29.17 & $0.925(2 ; 0.630)$ \\
\hline $\mathrm{f}$ & Exit of venture capitalists & $1.86(1.00)$ & 14.29 & $2.26(2.00)$ & 29.17 & $1.646(2 ; 0.439)$ \\
\hline $\mathrm{g}$ & Solving the problem of succession & $2.29(2.00)$ & 19.05 & $1.61(1.00)$ & 4.17 & $2.520(2 ; 0.284)$ \\
\hline $\mathrm{j}$ & Market value establishment & $3.48(4.00)$ & 61.90 & $3.50(3.50)$ & 45.83 & $2.917(2 ; 0.233)$ \\
\hline \multirow[t]{2}{*}{$\mathrm{k}$} & Acquisitions and mergers & $3.24(3.00)$ & 28.57 & $2.83(3.00)$ & 25.00 & $2.616(2 ; 0.270)$ \\
\hline & Non-financial determinants & & & & & \\
\hline $\mathrm{h}$ & Publicity, image enhancement & $3.43(4.00)$ & 52.38 & $3.22(3.00)$ & 45.83 & $0.988(2 ; 0.610)$ \\
\hline $\mathrm{i}$ & Attractiveness as an employer & $2.71(3.00)$ & 28.57 & $2.96(3.00)$ & 33.33 & $0.732(2 ; 0.693)$ \\
\hline
\end{tabular}

Note: Means are based on a five-point scale ranging from 1 (not important) to 5 (very important). The sample consisted of 45 completed surveys involving 21 young and 24 old companies. The $p$-values indicate simultaneous differences using the chi-square test.

Survey Results to the Question “How Important were/are the Following Determinants of Conducting an IPO”? (High-Tech and Conventional Companies)

\begin{tabular}{|c|c|c|c|c|c|c|}
\hline & & \multicolumn{5}{|c|}{ Industry } \\
\hline & & \multicolumn{2}{|c|}{ High-Tech } & \multicolumn{2}{|c|}{ Conventional } & \multirow{2}{*}{$\begin{array}{c}\text { Chi-Square Test (df; } \\
\text { p) }\end{array}$} \\
\hline & & Mean (Median) & $\begin{array}{c}\% \\
4-5\end{array}$ & Mean (Median) & $\begin{array}{c}\% \\
4-5\end{array}$ & \\
\hline $\mathrm{a}$ & Raising external capital & $3.82(4.00)$ & 81.82 & $3.12(3.00)$ & 47.06 & $4.43(2 ; 0.109)$ \\
\hline b & Reducing company indebtedness & $2.64(3.00)$ & 18.18 & $2.35(2.00)$ & 20.59 & $1.14(2 ; 0.566)$ \\
\hline c & Stronger bargaining position & $3.00(3.00)$ & 45.46 & $2.94(3.00)$ & 38.24 & $0.19(2 ; 0.909)$ \\
\hline $\mathrm{d}$ & Reducing the cost of capital & $2.70(3.00)$ & 30.00 & $2.45(3.00)$ & 24.24 & $1.10(2 ; 0.576)$ \\
\hline e & Equity portfolio diversification & $2.36(2.00)$ & 18.18 & $2.03(2.00)$ & 12.12 & $1.29(2 ; 0.525)$ \\
\hline$f$ & Exit of venture capitalists & $2.27(2.00)$ & 27.27 & $2.00(1.00)$ & 21.21 & $1.51(2 ; 0.470)$ \\
\hline $\mathrm{g}$ & Solving the problem of succession & $2.27(3.00)$ & 18.18 & $1.82(1.00)$ & 9.09 & $4.57(2 ; 0.102)$ \\
\hline $\mathrm{j}$ & Market value establishment & $3.50(4.00)$ & 60.00 & $3.48(4.00)$ & 54.55 & $0.66(2 ; 0.719)$ \\
\hline \multirow[t]{2}{*}{$\mathrm{k}$} & Acquisitions and mergers & $3.36(3.00)$ & 45.46 & $2.91(3.00)$ & 21.21 & $2.45(2 ; 0.294)$ \\
\hline & Non-financial determinants & & & & & \\
\hline $\mathrm{h}$ & Publicity, image enhancement & $3.36(4.00)$ & 54.56 & $3.30(3.00)$ & 48.49 & $1.03(2 ; 0.596)$ \\
\hline $\mathrm{i}$ & Attractiveness as an employer & $2.91(3.00)$ & 27.27 & $2.82(3.00)$ & 33.33 & $0.52(2 ; 0.770)$ \\
\hline
\end{tabular}

Note: Means are based on a five-point scale ranging from 1 (not important) to 5 (very important). The sample consisted of 45 completed surveys involving 11 companies operating in high-tech and 34 companies operating in conventional industries. The $p$-values indicate simultaneous differences using the chi-square test. 
Survey Results to the Question "How Important were/are the Following Determinants of Conducting an IPO"? (Companies with Domestic and Foreign Ownership)

\begin{tabular}{|c|c|c|c|c|c|c|}
\hline & & \multicolumn{5}{|c|}{ Ownership } \\
\hline & & \multicolumn{2}{|c|}{ Domestic } & \multicolumn{2}{|c|}{ Foreign } & \multirow[b]{2}{*}{$\begin{array}{c}\text { Chi-Square Test (df; } \\
\text { p) }\end{array}$} \\
\hline & & Mean (Median) & $\begin{array}{l}\% \\
4-5\end{array}$ & Mean (Median) & $\begin{array}{c}\% \\
4-5\end{array}$ & \\
\hline & \multicolumn{6}{|l|}{ Financial determinants } \\
\hline $\mathrm{a}$ & Raising external capital & $3.38(4.00)$ & 58.62 & $3.13(3.50)$ & 50.00 & $0.31(2 ; 0.856)$ \\
\hline $\mathrm{b}$ & Reducing company indebtedness & $2.31(2.00)$ & 17.24 & $2.63(2.00)$ & 25.00 & $0.64(2 ; 0.725)$ \\
\hline $\mathrm{c}$ & Stronger bargaining position & $2.83(3.00)$ & 31.03 & $3.19(4.00)$ & 56.25 & $2.82(2 ; 0.244)$ \\
\hline d & Reducing the cost of capital & $2.57(3.00)$ & 28.57 & $2.40(3.00)$ & 33.34 & $0.39(2 ; 0.825)$ \\
\hline $\mathrm{e}$ & Equity portfolio diversification & $2.03(2.00)$ & 10.35 & $2.27(2.00)$ & 33.34 & $0.98(2 ; 0.613)$ \\
\hline$f$ & Exit of venture capitalists & $1.90(1.00)$ & 17.24 & $2.40(2.00)$ & 33.34 & $2.31(2 ; 0.315)$ \\
\hline $\mathrm{g}$ & Solving the problem of succession & $2.14(2.00)$ & 13.79 & $1.53(1.00)$ & 6.67 & $2.95(2 ; 0.229)$ \\
\hline $\mathrm{j}$ & Market value establishment & $3.46(4.00)$ & 53.57 & $3.53(4.00)$ & 60.00 & $0.38(2 ; 0.828)$ \\
\hline \multirow[t]{2}{*}{$\mathrm{k}$} & Acquisitions and mergers & $3.17(3.00)$ & 27.59 & $2.73(3.00)$ & 26.67 & $6.39(2 ; 0.409)$ \\
\hline & Non-financial determinants & & & & & \\
\hline $\mathrm{H}$ & Publicity, image enhancement & $3.28(3.00)$ & 44.83 & $3.40(4.00)$ & 60.00 & $1.16(2 ; 0.56)$ \\
\hline I & Attractiveness as an employer & $2.90(3.00)$ & 31.03 & $2.73(3.00)$ & 33.34 & $1.08(2 ; 0.58)$ \\
\hline
\end{tabular}

Note: Means are based on a five-point scale ranging from 1 (not important) to 5 (very important). The sample consisted of 45 completed surveys involving 29 companies with domestic ownership and 16 companies with foreign ownership. The $p$-values indicate simultaneous differences using the chi-square test

\section{Discussion}

Our evidence suggests that companies seek multiple benefits in going public strategy. This result is in accordance with Brau \& Fawcett's (2006) and Bancel \& Mittoo's findings (2009). Additionally, the CFOs' views are partially different in both investigated countries and statistically significant differences exist in motivations of companies, which differ in age and size.

Our first main conclusion is that a considerably larger number of CFOs (IPO candidates) is motivated by raising external equity capital. Surveyed companies tend to conduct an IPO in the expansion stage of their life cycle. This finding is line with the theoretical approach formulated by Ritter \& Welch (2002), who argue that most firms go public to raise fund for new projects. Our evidence is also consistent with previous questionnaire based surveys conducted in companies that had successfully completed an IPO in Europe. Bancel \& Mittoo (2009) surveyed CFOs in 12 European countries and identified funding for growth as the most important benefit of going public across all firms and countries.

A going public strategy is not perceived as an appropriate way how to reduce the cost of capital, achieve an optimal capital structure or lower the firm's leverage although these determinants attract a lot of attention in the theory of corporate finance (Scott, 1976; Modigliani \& Miller, 1958, 1963). Our findings with regard to the cost of capital and capital structure theories are similar to some prior empirical studies. Bancel \& Mittoo (2009) find less support for the cost of capital theories and Brau \& Fawcett (2006) also report that "CFO desire to minimize the cost of capital received relatively low scores". On the other hand, Czech and Polish CFOs' views are in contrast to Pagano et $a l$. (1998), who surveyed a unique data set of Italian firms, and who document that managers consider a public issue as a strategy how to "rebalance their balance sheets after large investments and growth" and how to "reduce the cost of credit".

We find a strong support for the theory that an IPO is a vehicle to enhance stock liquidity and firm market value.
Over half of Czech and Polish CFOs identify the market value establishment as a major IPO motivation. This result corresponds to the theory outlined in financial studies by Zingales (1995) and Black \& Gilson (1998) supporting the thesis the establishment of a market price may provide the existing shareholders more flexibility in their decision making. Using public shares in future mergers and acquisitions as an IPO determinant received a moderate support within our investigation. This is not consistent with prior financial studies. Brau \& Fawcett (2006) report that US CFOs feel most strongly that "an IPO serves to create public shares for use in future M\&A" and Bancel \& Mittoo's findings (2009) across European countries also support the notion that CFOs agree that "facilitating M\&A is important in their listing decision" and that "the IPO has allowed them to estimate the market value of the company and to use stock currency for future acquisitions". Taken together, the evidence suggests that Czech and Polish CFOs feel motivated by the idea that the listing enables valuing of the company; however, any consideration of takeover defences at the time of the IPO are not set up.

Regarding the non-financial motivations, we find a strong support for the theory formulated by Maksimovic \& Pichler (2001). Most of Czech and Polish CFOs strongly agree with the notion that the public trading of stocks can enhance the publicity and reputation of the firm. The prestige can be very advantageous in raising capital for growth, recruiting key employees as well as marketing products and services. Therefore, the views of our respondents are consistent with prior US and European studies. Brau \& Fawcett (2006) examined this IPO motivation on the US market and concluded that enhancing firm reputation and attracting analysts' attention motivate primarily smaller, younger, high-tech, and VC-backed firms while firms with large insider holdings are less concerned about this factor. Our results are also in line with a survey based research conducted by Bancel \& Mittoo (2009). The authors report that "most European CFOs indicate that enhancing the company's prestige and visibility and a broader shareholder base are major criteria for the listing decision". 
Our next set of conclusions is an output of analysing the conditioning variables.

Based on IPO considerations expressed by our respondents, we conclude that the Polish companies are more likely to conduct an IPO than their Czech counterparts. In this respect, our findings confirm a higher attractiveness of the Polish capital market from the perspective of issuers, as indicated in prior academic studies (Peterle \& Berk, 2016; Peterle, 2013; Kominek, 2003).

The CFOs' views differ partially across surveyed countries and companies varying in age and size.

First, we find strong support for the theories that focus on raising external capital (Ritter \& Welch, 2002), lowering the cost of capital (Rajan, 1992) and rebalancing the balance sheet (Scott, 1976; Modigliani \& Miller, 1958, 1963) within the Polish subsample. The support of Czech CFOs to these factors was rather low. Both surveyed groups, however, share similar views in other aspects. Both Czech and Polish CFOs consider market value establishment and publicity and image enhancement as major benefits of going public. In this regard, our survey findings are similar to results presented in European financial studies. Bancel \& Mittoo (2009) identified enhanced reputation, funding for growth and financial flexibility as the most important benefits of going public across all firms and European countries. This "European" attitude towards IPO contradicts, however, the views of US COFs as reported by Ritter \& Welch (2002): "Non-financial reasons, such as increased publicity, play only a minor role for most US firms".

Second, the frequency of positive answers to the issue of IPO considerations does not indicate that there is a significant difference between old and young companies, although Chemmanur \& Fulghieri (1999) believe that a going public strategy deserves attention especially in the case of mature and well established companies. According to Pagano et al. (1998) and Rydqvist \& Hogholm (1995) the average age of firms going public in continental Europe is higher, which is in contrast with the US, where many startups implement public issue to finance their expansion.

Czech and Polish CFOs working in older firms aim to strengthen the bargaining power with banks and one third of them believe an IPO could be a tool to reduce leverage. This finding may reflect that mature companies prefer using funds raised by IPO to pay down debt and corresponds to the results of previous studies conducted in continental Europe (Pagano et al., 1998; Rydqvist \& Hogholm, 1995). Both young and old companies consider raising funds, market value establishment and publicity enhancement as major IPO benefits.

Third, over $50 \%$ of CFOs operating in small companies are significantly more motivated to borrow more cheaply. Given many small private companies state that their financing is dependent on bank loans, this finding is not surprising. The factor of lowering the cost of capital creates a big part of substantial academic theory (Scott, 1976; Modigliani \& Miller, 1958, 1963). Czech and Polish CFOs from large companies are significantly less concerned about enhancing the reputation of the firm. This feature differs them from their small peers and is in line with many reported empirical findings and theories. Brau \& Fawcett's investigation (2006) reveals that publicity and image enhancement as IPO motivation prevails in smaller, younger, high-tech, and VC-backed firms and Maksimovic \& Pichler (2001) argue that company listing might be a source of reputational capital with a positive impact on sales, employees and financial strategy. In regard to the image enhancement, however, our analysis does not indicate any differences between companies operating in high-tech and conventional industries. We identified this motivation as very important in both subsamples.

Finally, our evidence contradicts the theory that enterprises with foreign ownership are less motivated to go public due to alternative opportunities how to raise external capital outside the organized capital market (Egger et al., 2010). No differences between companies with domestic and foreign ownership in regard to the individual IPO factors could be identified.

\section{Conclusions}

Our survey proves internal going public determinants on two CEE capital markets, which differ substantially in their development in the last two decades. While a significant number of IPOs confirms the attractiveness of the Polish primary capital market for both investors and issuers, the Prague Stock Exchange as a source of investment capital has faced a lack of interest (Peterle, 2013; Kominek, 2003).

We surveyed 27 Czech and 18 Polish CFOs from companies that are considered to be IPO candidates.

Our findings indicate that the decision making on going public can be explained by a larger number of theories formulated for well-developed capital markets and might be affected by external factors such as macro and capital market factors, cultural differences, historical developments as well as by firm's specific characteristics (internal factors).

The summarized key conclusions of our research are as follows.

The most important IPO motivations are enhanced publicity and reputation of the company and establishment of the firm's market value. These benefits are expressed by CFOs across all firms and in both countries. However, the significance of other going public determinants differs between Czech and Polish respondents and across companies varying in size and age. Polish CFOs strongly agree with the notion that an IPO serves as a tool how to raise external equity, lower the cost of capital and optimize the capital structure. Surprisingly, Czech CFOs are less concerned about these factors. Thus, we conclude that the main internal IPO drivers in Poland are similar to those reported from well-developed markets in continental Europe, whereas Czech firms do not feel attracted by them because their financing is traditionally based on banking financial environment.

The CFOs views on IPO are similar in both old and young firms. The respondents feel strongly motivated by the market value establishment, publicity and image enhancement and raising external capital. Older companies, however, are significantly more driven by leverage reducing and strengthening the bargaining power with banks than their young peers. 
Survey Results to the Question “How Important were/are the Following Determinants of Conducting an IPO”? (Small and Large Companies)

\begin{tabular}{|c|c|c|c|c|c|c|c|c|c|c|c|c|c|c|c|c|}
\hline & & \multicolumn{5}{|c|}{ Employees } & \multicolumn{5}{|c|}{ Assets } & \multicolumn{5}{|c|}{ Sales } \\
\hline & & \multicolumn{2}{|c|}{ Small } & \multicolumn{2}{|c|}{ Large } & \multirow{2}{*}{$\begin{array}{c}\text { Chi- } \\
\text { Square } \\
\text { Test } \\
\text { (df; p) }\end{array}$} & \multicolumn{2}{|c|}{ Small } & \multicolumn{2}{|c|}{ Large } & \multirow{2}{*}{$\begin{array}{l}\text { Chi- } \\
\text { Square } \\
\text { Test } \\
\text { (df; p) }\end{array}$} & \multicolumn{2}{|c|}{ Small } & \multicolumn{2}{|c|}{ Large } & \multirow{2}{*}{$\begin{array}{c}\text { Chi- } \\
\text { Square } \\
\text { Test } \\
\text { (df; p) }\end{array}$} \\
\hline & & $\begin{array}{c}\text { Mean } \\
\text { (Median) }\end{array}$ & $\begin{array}{c}\% \\
4-5\end{array}$ & $\begin{array}{c}\text { Mean } \\
\text { (Median) }\end{array}$ & $\begin{array}{c}\% \\
4-5\end{array}$ & & $\begin{array}{c}\text { Mean } \\
\text { (Median) }\end{array}$ & $\begin{array}{c}\% \\
4-5\end{array}$ & $\begin{array}{c}\text { Mean } \\
\text { (Median) }\end{array}$ & $\begin{array}{l}\% \\
4-5\end{array}$ & & $\begin{array}{c}\text { Mean } \\
\text { (Median) }\end{array}$ & $\begin{array}{c}\% \\
4-5\end{array}$ & $\begin{array}{c}\text { Mean } \\
\text { (Median) }\end{array}$ & $\begin{array}{l}\% \\
4-5\end{array}$ & \\
\hline & \multicolumn{16}{|l|}{$\begin{array}{l}\text { Financial } \\
\text { determinants }\end{array}$} \\
\hline $\mathrm{a}$ & $\begin{array}{l}\text { Raising } \\
\text { external } \\
\text { capital }\end{array}$ & $\begin{array}{c}4.30 \\
(4.50)\end{array}$ & 80.00 & $\begin{array}{c}3.00 \\
(3.00)\end{array}$ & 48.57 & $\begin{array}{l}6.58(2 ; \\
0.037)\end{array}$ & $\begin{array}{c}3.91 \\
(4.00)\end{array}$ & 72.73 & $\begin{array}{c}3.09 \\
(3.50)\end{array}$ & 50.00 & $\begin{array}{c}3.99(2 ; \\
0.136)\end{array}$ & $\begin{array}{c}4.29 \\
(5.00)\end{array}$ & 71.43 & $\begin{array}{c}3.11 \\
(4.00)\end{array}$ & 52.63 & $\begin{array}{c}5.41(2 ; \\
0.067)\end{array}$ \\
\hline b & $\begin{array}{l}\text { Reducing } \\
\text { company } \\
\text { indebtedness }\end{array}$ & $\begin{array}{c}2.60 \\
(2.50)\end{array}$ & 10.00 & $\begin{array}{l}2.37 \\
(2.00)\end{array}$ & 22.86 & $\begin{array}{l}1.99(2 ; \\
0.370)\end{array}$ & $\begin{array}{c}2.55 \\
(3.00)\end{array}$ & 9.09 & $\begin{array}{c}2.38 \\
(2.00)\end{array}$ & 23.53 & $\begin{array}{c}3.76(2 ; \\
0.152)\end{array}$ & $\begin{array}{c}3.13 \\
(3.00)\end{array}$ & 14.29 & $\begin{array}{c}2.37 \\
(2.00)\end{array}$ & 21.05 & $\begin{array}{c}1.53(2 ; \\
0.466)\end{array}$ \\
\hline $\mathrm{c}$ & $\begin{array}{l}\text { Stronger } \\
\text { bargaining } \\
\text { position }\end{array}$ & $\begin{array}{c}3.30 \\
(3.00)\end{array}$ & 40.00 & $\begin{array}{c}2.86 \\
(3.00)\end{array}$ & 40.00 & $\begin{array}{c}3.06(2 ; \\
0.216)\end{array}$ & $\begin{array}{c}3.09 \\
(3.00)\end{array}$ & 36.36 & $\begin{array}{c}2.91 \\
(3.00)\end{array}$ & 41.18 & $\begin{array}{c}1.59(2 \\
0.452)\end{array}$ & $\begin{array}{c}3.14 \\
(3.00)\end{array}$ & 28.57 & $\begin{array}{c}2.92 \\
(3.00)\end{array}$ & 42.11 & $\begin{array}{c}2.69(2 ; \\
0.261)\end{array}$ \\
\hline d & $\begin{array}{l}\text { Reducing the } \\
\text { cost of capital }\end{array}$ & $\begin{array}{c}3.56 \\
(4.00)\end{array}$ & 50.00 & $\begin{array}{c}2.24 \\
(2.00)\end{array}$ & 17.65 & $\begin{array}{l}9.79(2 ; \\
0.007)\end{array}$ & $\begin{array}{c}3.40 \\
(4.00)\end{array}$ & 60.00 & $\begin{array}{c}2.24 \\
(2.00)\end{array}$ & 15.15 & $\begin{array}{c}9.48(2 ; \\
0.009)\end{array}$ & $\begin{array}{c}3.57 \\
(4.00)\end{array}$ & 57.14 & $\begin{array}{c}2.31 \\
(2.00)\end{array}$ & 19.44 & $\begin{array}{c}7.39(2 ; \\
0.025)\end{array}$ \\
\hline $\mathrm{e}$ & $\begin{array}{l}\text { Equity } \\
\text { portfolio } \\
\text { diversification }\end{array}$ & $\begin{array}{c}2.50 \\
(2.50)\end{array}$ & 20.00 & $\begin{array}{c}2.00 \\
(2.00)\end{array}$ & 11.77 & $\begin{array}{l}2.06(2 ; \\
0.367)\end{array}$ & $\begin{array}{c}2.36 \\
(2.00)\end{array}$ & 18.18 & $\begin{array}{c}2.03 \\
(2.00)\end{array}$ & 12.12 & $\begin{array}{l}1.29(2 ; \\
0.525)\end{array}$ & $\begin{array}{c}2.57 \\
(2.00)\end{array}$ & 28.57 & $\begin{array}{c}2.03 \\
(2.00)\end{array}$ & 10.81 & $\begin{array}{c}1.58(2 ; \\
0.454)\end{array}$ \\
\hline f & $\begin{array}{l}\text { Exit of } \\
\text { venture } \\
\text { capitalists }\end{array}$ & $\begin{array}{l}2.50 \\
(2.00)\end{array}$ & 30.00 & $\begin{array}{c}1.94 \\
(1.00)\end{array}$ & 20.59 & $\begin{array}{l}1.48(2 ; \\
0.476)\end{array}$ & $\begin{array}{l}2.55 \\
(2.00)\end{array}$ & 27.27 & $\begin{array}{c}1.91 \\
(1.00)\end{array}$ & 21.21 & $\begin{array}{l}0.18(2 ; \\
0.915)\end{array}$ & $\begin{array}{c}2.57 \\
(2.00)\end{array}$ & 28.57 & $\begin{array}{c}1.97 \\
(1.00)\end{array}$ & 21.62 & $\begin{array}{c}0.90(2 ; \\
0.639)\end{array}$ \\
\hline g & $\begin{array}{l}\text { Solving the } \\
\text { problem of } \\
\text { succession }\end{array}$ & $\begin{array}{c}1.80 \\
(1.00)\end{array}$ & 10.00 & $\begin{array}{c}1.97 \\
(1.50)\end{array}$ & 11.77 & $\begin{array}{l}0.45(2 \\
0.978)\end{array}$ & $\begin{array}{c}1.91 \\
(1.00)\end{array}$ & 9.09 & $\begin{array}{c}1.94 \\
(1.00)\end{array}$ & 12.12 & $\begin{array}{c}0.83(2 ; \\
0.660)\end{array}$ & $\begin{array}{c}1.71 \\
(1.00)\end{array}$ & 0.00 & $\begin{array}{c}1.97 \\
(1.00)\end{array}$ & 13.51 & $\begin{array}{c}1.44(2 ; \\
0.486)\end{array}$ \\
\hline $\mathrm{j}$ & $\begin{array}{l}\text { Market value } \\
\text { establishment }\end{array}$ & $\begin{array}{c}3.80 \\
(4.00)\end{array}$ & 70.00 & $\begin{array}{c}3.39 \\
(4.00)\end{array}$ & 50.00 & $\begin{array}{c}2.99(2 ; \\
0.224)\end{array}$ & $\begin{array}{c}3.19 \\
(4.00)\end{array}$ & 72.73 & $\begin{array}{c}3.38 \\
(3.50)\end{array}$ & 50.00 & $\begin{array}{c}3.52(2 ; \\
0.172)\end{array}$ & $\begin{array}{c}3.86 \\
(4.00)\end{array}$ & 71.43 & $\begin{array}{c}3.42 \\
(4.00)\end{array}$ & 52.78 & $\begin{array}{c}1.95(2 ; \\
0.377)\end{array}$ \\
\hline $\mathrm{k}$ & $\begin{array}{l}\text { Acquisitions } \\
\text { and mergers }\end{array}$ & $\begin{array}{c}3.00 \\
(3.00) \\
\end{array}$ & 20.00 & $\begin{array}{c}3.03 \\
(3.00) \\
\end{array}$ & 29.41 & $\begin{array}{c}0.39(2 \\
0.821)\end{array}$ & $\begin{array}{c}2.73 \\
(3.00) \\
\end{array}$ & 18.18 & $\begin{array}{c}3.12 \\
(3.00) \\
\end{array}$ & 30.30 & $\begin{array}{c}3.30(2 ; \\
0.192)\end{array}$ & $\begin{array}{c}2.86 \\
(3.00) \\
\end{array}$ & 14.29 & $\begin{array}{c}3.05 \\
(3.00) \\
\end{array}$ & 29.73 & $\begin{array}{c}1.62(2 ; \\
0.445)\end{array}$ \\
\hline & $\begin{array}{l}\text { Non-financial } \\
\text { determinants }\end{array}$ & & & & & & & & & & & & & & & \\
\hline $\mathrm{h}$ & $\begin{array}{l}\text { Publicity, } \\
\text { image } \\
\text { enhancement }\end{array}$ & $\begin{array}{c}4.20 \\
(4.00)\end{array}$ & 80.00 & $\begin{array}{l}3.06 \\
(3.00)\end{array}$ & 41.18 & $\begin{array}{l}5.37(2 \\
0.068)\end{array}$ & $\begin{array}{c}4.18 \\
(4.00)\end{array}$ & 81.81 & $\begin{array}{c}3.03 \\
(3.00)\end{array}$ & 39.39 & $\begin{array}{l}6.61(2 ; \\
0.036)\end{array}$ & $\begin{array}{c}4.00 \\
(4.00)\end{array}$ & 71.43 & $\begin{array}{c}3.19 \\
(3.00)\end{array}$ & 45.94 & $\begin{array}{c}2.47(2 ; \\
0.291)\end{array}$ \\
\hline $\mathrm{i}$ & $\begin{array}{l}\text { Attractiveness } \\
\text { as an } \\
\text { employer }\end{array}$ & $\begin{array}{c}3.30 \\
(3.50)\end{array}$ & 50.00 & $\begin{array}{c}2.71 \\
(3.00)\end{array}$ & 26.47 & $\begin{array}{l}2.06(2 ; \\
0.358)\end{array}$ & $\begin{array}{c}3.27 \\
(3.00)\end{array}$ & 45.46 & $\begin{array}{c}2.70 \\
(3.00)\end{array}$ & 27.27 & $\begin{array}{l}1.71(2 ; \\
0.424)\end{array}$ & $\begin{array}{c}3.00 \\
(3.00)\end{array}$ & 42.86 & $\begin{array}{c}2.81 \\
(3.00)\end{array}$ & 29.73 & $\begin{array}{c}0.49(2 ; \\
0.785)\end{array}$ \\
\hline
\end{tabular}

Note: Means are based on a five-point scale ranging from 1 (not important) to 5 (very important). The $p$-values indicate simultaneous differences using the chi-square test. The sample consisted of 45 completed surveys involving 10 small and 35 large companies based on the number of employees or 11 small and 34 large companies based on value of assets or 7 small and 38 large companies based on value of sales.

Most CFOs from small companies agree that going public is a tool how to lower the cost of capital and how to enhance the reputation of the firm. Large companies are significantly less motivated by these factors. Nevertheless, we document a strong support to raising external capital and market value establishment in both groups of companies.

We also provide a unique comparison between CFOs' views in high-tech and conventional industries. Contrary to some recent findings for developed capital markets we could not identify any disparities between both peers. Similarly, CFOs from companies with domestic and foreign ownership express the same attitudes towards IPO motivations. Therefore, we argue that the industry and ownership have not significant impact on considerations about going public determinants.

Our outcomes provide valuable implications for issuers, investment bankers, stock exchanges and macroeconomic policy makers while formulating financial strategies and incentives how to increase the attractiveness of smaller emerging capital markets.
While the survey methodology provides direct insights expressed by CFOs on the one hand, it may be a source of some limitations on the other hand. According to accepted academic papers (e.g. Brau \& Fawcett, 2006) we should point out at least the following concerns: CFOs do not represent all decision makers, a sample bias cannot be excluded because there is no public available list of representative population and finally, we surveyed enterprises in the period following the financial and economic crisis, which might have changed CFOs' perspectives.

In a follow-up research we aim to extend the data experiment to other points in time (a longitudinal study is a possibility) and involve more countries within the CEE region. We could also enhance the existing list of determinants by including variables related with e.g. ownership and governance as reported by Bertoni et al. (2014). A lack of knowledge about IPO determinants could be one of the main internal obstacles to development of young CEE capital markets.

\section{Acknowledgment}

The research is covered by Institute of Economic Research Torun. Name of the Project: Analysis of Relations among Capital Markets of European Union Countries. Project Registration No. 2016/1. 


\section{References}

Bancel, F., \& Mittoo, U. R. (2009). Why Do European Firms Go Public? European Financial Management, 15 (4), 844-884. http://dx.doi.org/ 10.1111/j.1468-036X.2009.00501.x

Benninga, S., Helmantel, M., \& Sarig, O. (2005). The timing of initial public offerings. Journal of Financial Economics, 75 (1), 115-132. http://dx.doi.org/10.1016/j.jfineco.2003.04.002

Bertoni, F., Meoli, M., \& Vismara, S. (2014). Board Independence, Ownership Structure and the Valuation of IPOs in Continental Europe. Corporate Governance: An International Review, 22 (2), 116-131. http://dx.doi.org/10. 1111/corg.12051

Bistrova, J., Lace, N., \& Peleckiene, V. (2011). The influence of capital structure on Baltic corporate performance. Journal of Business Economics and Management, 12 (4), 655-669. http://dx.doi.org/10.3846/16111699. 2011.599414

Bistrova, J., \& Lace, N. (2010). Ownership structure in CEE companies and its influence on stock performance. Economics and Management, 15, 880-885.

Bistrova, J., \& Lace, N. (2011). Corporate Financial Strength Sustainability Post PO: Evidence from Baltic Equity Market. Economics and Management, 16, 1082-1088.

Black, B. S., \& Gilson, R. J. (1998). Venture capital and the structure of capital markets: Banks versus stock markets. Journal of Financial Economics, 47 (3), 243-277. http://dx.doi.org/10.1016/S0304-405X(97)00045-7

Brau, J. C., Couch, R., \& Sutton, N. (2012). The Desire to Acquire and IPO Long-Run Performance. Journal of Financial and Quantitative Analysis, 47 (3). http://dx.doi.org/10.2139/ssrn.1270796

Brau, J. C., \& Fawcett, S. E. (2006). Initial Public Offerings: An Analysis of Theory and Practise. Journal of Finance, 61 (1), 399-436. http://dx.doi.org/10.1111/j.1540-6261.2006.00840.x

Celikyurt, U., Sevilir, M., \& Shivdasani, A. (2010). Going Public to Acquire? The Acquisition Motive in IPOs. Journal of Financial Economics, 96, 345-363. http://dx.doi.org/10.1016/j.jfineco.2010.03.003

Chemmanur, T. J. \& Fulghiery, A. (1999). Theory of the Going-Public Decision. Review of Financial Studies, 12 (2), 249-279. http://dx.doi.org/10.1093/rfs/12.2.249

Commission Regulation (EC) No 800/2008

Commission Regulation (EC) No 795/2013

Egger. P., Eggert, W., Keuschnigg C., \& Winner, H. (2010). Corporate taxation, debt financing and foreign-plant ownership. European Economic Review, 56 (4), 635-647. http://dx.doi.org/10.1016/j.euroecorev.2012.02.015

Gunther, S., \& Rummer, M. (2006). The hot-issue period in Germany: what factors drove IPO underpricing? In Gregoriou, G. N. (ed.) Initial Public Offerings: An International Perspective, Oxford: Butterworth-Heinemann, 215-245. http://dx.doi.org/10.1016/b978-075067975-6.50017-7

Hovakimian, A., \& Hutton, I. (2010). Merger Motivated IPOs. Financial Management 39 (4), 1547-1573. http://dx.doi.org/10.1111/j.1755-053X.2010.01122.x

Jargot, A. (2006). Why polish companies go public: an analysis of determinants and consequences of the initial public offering (MSc in Finance \& International Business). Aarhus: Aarhus School of Business.

Kominek, Z. (2003). Stock markets and industry growth: an eastern European perspective. London: EBRD, Working Paper No. 81.

Lizinska, J., \& Czapiewski, L. (2016). Is the IPO Anomaly in Poland Only Apparent of Real? In the Essence and Measurement of Organizational Efficiency, Springer International Publishing, 175-194. http://dx.doi.org/10. 1007/978-3-319-21139-8_10

Ljungqvist, A. P. (1995). When do firms go public? Poisson evidence from Germany. Oxford: University of Oxford, Working Paper.

Lyandres, E., Zhdanov, A., \& Hsieh, J. (2011). A Theory of Merger-driven IPOs. Journal of Financial and Quantitative Analysis forthcoming, 46, 1367-1405. http://dx.doi.org/ 10.2139/ssrn.932117.

Maksimovic, V., \& Pichler, P. (2001). Technological innovation and initial public offerings. Review of Financial Studies, 14, 459-494. http://dx.doi.org/10.1093/rfs/14.2.459 
Meluzin, T., \& Zinecker, M. (2014a). Reasons for IPO Implementation: Empirical Evidence from the Polish Capital Market. Inzinerine Ekonomika-Engineering Economics, 25 (3), 654-673. http://dx.doi.org/10.5755/j01.ee. 25.3.3529

Meluzin, T., \& Zinecker, M. (2014b). Determinanten der Entscheidung fur eine Borseneinfuhrung unter den Bedingungen des polnischen Kapitalmarktes - Ergebnisse einer empirischen Untersuchung. Betriebswirtschaftliche Forschung und Praxis (BFuP), 66 (6), 294-301.

Modigliani, F., \& Miller, M. (1958). The Cost of Capital, Corporation Finance and the Theory of Investment. American Economic Review, 53 (3), 433-43.

Modigliani, F., \& Miller, M. (1963). Corporate Income Taxes and the Cost of Capital: a Correction. American Economic Review, 48, 261-297.

Pagano, M., Panetta, F., \& Zingales, L. (1998). Why do companies go public: An empirical analysis. Journal of Finance, 53, 27-64. http://dx.doi.org/10.1111/0022-1082.25448

Peterle, P. (2013). Internal characteristics and external factors of IPO activities in Central and Eastern Europe: Empirical analysis and comparison. Ljubljana: Faculty of Economics of the University of Ljubljana, Working Paper.

Peterle, P., \& Berk, A. (2016). IPO Cycles in Central and Eastern Europe: What Factors Drive these Cycles? Czech Journal of Economics and Finance, 66 (2), 113-139.

Rajan, R. G. (1992). Insiders and outsiders: the choice between informed and arm's-length debt. Journal of Finance, 47, 1367-1400. http://dx.doi.org/10.1111/j.1540-6261.1992.tb04662.x

Ritter, J. R. (2011). Equilibrium in the IPO Market. Financial Economics, 3, 347-374. http://dx.doi.org/10. 2139/ssrn.1822542

Ritter, J. R., \& Welch, I. (2002). A review of IPO activity, pricing, and allocations. Journal of Finance, 57 (4), 1795-1828. http://dx.doi.org/10.1111/1540-6261.00478

Rydqvist, K., \& Hogholm, K. (1995). Going public in the 1980s: Evidence from Sweden. European Financial Management, 1 (3), 287-315. http://dx.doi.org/10.1111/j.1468-036X.1995.tb00021.x

Scott, J. H. (1976). A theory of optimal capital structure. The Bell Journal of Economics, 7(1), 33-54. http://dx.doi.org/10.2307/3003189

Snieska, V., Venckuviene, V., \& Masteikiene, R. (2016). The Prognostics for Credit Shocks (Financial Crisis) and Insights for Mitigating Consequences. Inzinerine Ekonomika-Engineering Economics, 27(1), 47-55. http://dx.doi.org/ 10.5755/j01.ee.27.1.9533

Snieska, V., \& Venckuviene, V. (2011). Hybrid Venture Capital Funds in Lithuania: Motives, Factors and Present State of Development. Inzinerine Ekonomika-Engineering Economics, 22(2), 157-164. http://dx.doi.org/ 10.5755/j01. ee.22.2.312

Zingales, L. (1995). Insider Ownership and the Decision to Go Public. Review of Economic Studies, 62, $425-448$. http://dx.doi.org/10.2307/2298036

The article has been reviewed.

Received in April, 2016; accepted in August, 2016. 